\title{
Life history and emergence patterns of stonefly species in mountain streams of the Futaleufú basin, Patagonia (Argentina)
}

\author{
M.E.T. Hollmann, M.L. Miserendino*
}

LIESA. Laboratorio de Investigaciones en Ecología y Sistemática Animal. Universidad Nacional de la Patagonia. Sarmiento 849.9200 Esquel, Chubut, Argentina.

\begin{abstract}
The temporal dynamics in density, life histories, and emergence patterns were described for the first time for five Plecoptera species in tributaries of the Futaleufú River in Patagonia, Argentina. Benthic samples and adult collections were made in five low order Nothofagus forested streams. Four species of Gripopterygidae; Aubertoperla illiesi, Notoperlopsis femina, Antarctoperla michaelseni and Senzilloides panguipulli had simple, highly synchronized univoltine life histories. The austroperlid Klapopteryx kuscheli takes more than two years to develop. Emergence periods of most of the species were concentrated in late spring and summer (October to February), which suggests seasonal and synchronized life histories. Most N. femina adults were collected in mid spring indicating this species emerged first, whereas $S$. panguipulli emerged last from January to April. Aubertoperla illiesi showed a slightly delayed emergence at the high elevation site (La Hoya Stream) when compared to a piedmont stream, suggesting that temperature was an important control. Although we were unable to describe the life history of Limnoperla jaffueli (Gripopterygidae) its adult emergence period was November to January. Life histories of Plecoptera species in the studied streams seem to have a high degree of seasonality at least at this latitude, and are possibly determined by predictable temperature patterns and discharge regimes. This first contribution on the life histories of Plecoptera species helps us to better understand the dynamics and functioning of pristine but fragile aquatic environments in Patagonia.
\end{abstract}

Keywords: aquatic insects; life history; Plecoptera; river; synchronicity; voltinism.

\section{Introduction}

Plecoptera nymphs are a conspicuous component of the macroinvertebrate fauna in pristine mountain streams worldwide (Short \& Ward 1980). In Patagonian running waters (South America), stoneflies constitute a highly diversified and specialized group of aquatic insects (Wais et al. 1987). Only six of the 17 Plecoptera families (Eustheniidae, Diamphipnoidae, Austroperlidae, Gripopterygidae, Notonemouridae and Perlidae) are present in the region (Illies 1965) and as is usual with Plecoptera in the Southern Hemisphere the genera are endemic to their particular landmass (Mc Lellan 2001). This is a frequent characteristic of the stoneflies inhabiting Patagonian aquatic environments.

The ecological knowledge of stoneflies in the mountainous area of Patagonia has increased notably with recent studies. The altitudinal distributions of Plecoptera assemblages have been described by Albariño (1997) and Miserendino \& Pizzolón (2000) and functional feed-

\footnotetext{
* Corresponding author: Email: 1miserendino@liesa.org.ar
}

ing behaviours of some abundant species have been the focus of other research (Albariño \& Balseiro 1998, Hollmann \& Miserendino 2004). Plecoptera communities have been used to assess organic pollution (Miserendino 2000) and to evaluate land use effects in watersheds affected by agriculture and cattle ranching (Miserendino \& Pizolón 2004, Miserendino 2006). However, and in contrast with the situation in the Northern Hemisphere (Harper et al.1991, Sheldon 1999, Tierno de Figueroa et al. 2001, Richardson 2001) and other countries of the Southern Hemisphere (Winterbourn et al. 1981, Bunn 1988), little is known about the life histories and emergence periods of aquatic insects in Patagonia (Hollmann \& Miserendino 2006). In particular, no life history studies have been made on Plecoptera species in Patagonia.

Studies on aquatic insects in temperate regions suggest that life histories are tuned to the seasonal availability of food, and that related species are temporally segregated (Vannote et al. 1980, Richardson 1991). On the contrary, some stream insects in the Southern Hemisphere, such as those in New Zealand, have been characterized as having flexible, poorly synchronized life histories with non-sea- 
sonal patterns of development and extended flight periods (Winterbourn 1981). This apparent flexibility may be related to climatic stability, unpredictability of discharge, and a greater continuity in supply of allochthonous inputs (Winterbourn 1995, Scarsbrook 2000). The running water fauna of Patagonia show strong biogeographical affinities with that of New Zealand (Boothroyd 2000, Hitchings \& Staniczek 2003). However, rivers in the Patagonian Mountains are more predictable in terms of annual discharge patterns and one might expect the life histories of stream insects to demonstrate a greater degree of synchrony in growth (Miserendino \& Pizzolón 2003). Nevertheless, recent studies of life histories of common mayfly species in the Patagonian area show that synchrony of growth is lower than expected (Gonser \& Spies 1997, Hollman \& Miserendino 2006).

Knowledge of life histories and emergence periods of aquatic insects is crucial for understanding species biology and behaviour, and also for aquatic conservation purposes (Stazner \& Resh 1993, Cayrou \& Céréghino 2005). For example, life history studies and knowledge of the emergence periods of species in an area can help to improve the use and interpretation of biotic indices (Sheldon 1999). Most stonefly species are stenothermic; consequently, changes in thermal regime of watercourses can limit their distribution (Ward 1985, Quinn \& Hickey 1990). In particular, the distributions and life histories of stoneflies can be strongly affected by river regulation (Perry et al. 1986, Brittain 1991, Miserendino \& Stanford 2004).

In previous studies carried out in rivers of the Futaleufú Basin, Patagonia, larval Gripopterygidae and Austroperlidae were found to contribute strongly to benthic community density and production (Miserendino 2001, Miserendino \& Pizzolón 2004). The species considered in the present study are abundant and frequently recorded in different rivers and streams in the Patagonian mountain ranges (Miserendino \& Pizzolón 2000, 2003). In this paper we examine the life histories and emergence patterns of five stonefly species: Aubertoperla illiesi (Froehlich), Notoperlopsis femina (Illies), Antarctoperla michaelseni (Klapálak), Senzilloides panguipulli (Navás) and Klapopteryx kuscheli (Illies), inhabiting tributaries within the Futaleufú River basin, Patagonia.

\section{Study area and methods}

Life history studies were carried out at five sites in the Futaleufú Basin, Chubut Province (Fig. 1). La Hoya Stream is a $2^{\text {nd }}$ order watercourse in the Esquel-Percy river drainage system. The study site is located in the mountainous zone at 1237 m.a.s.l (Fig. 1) and is sur-

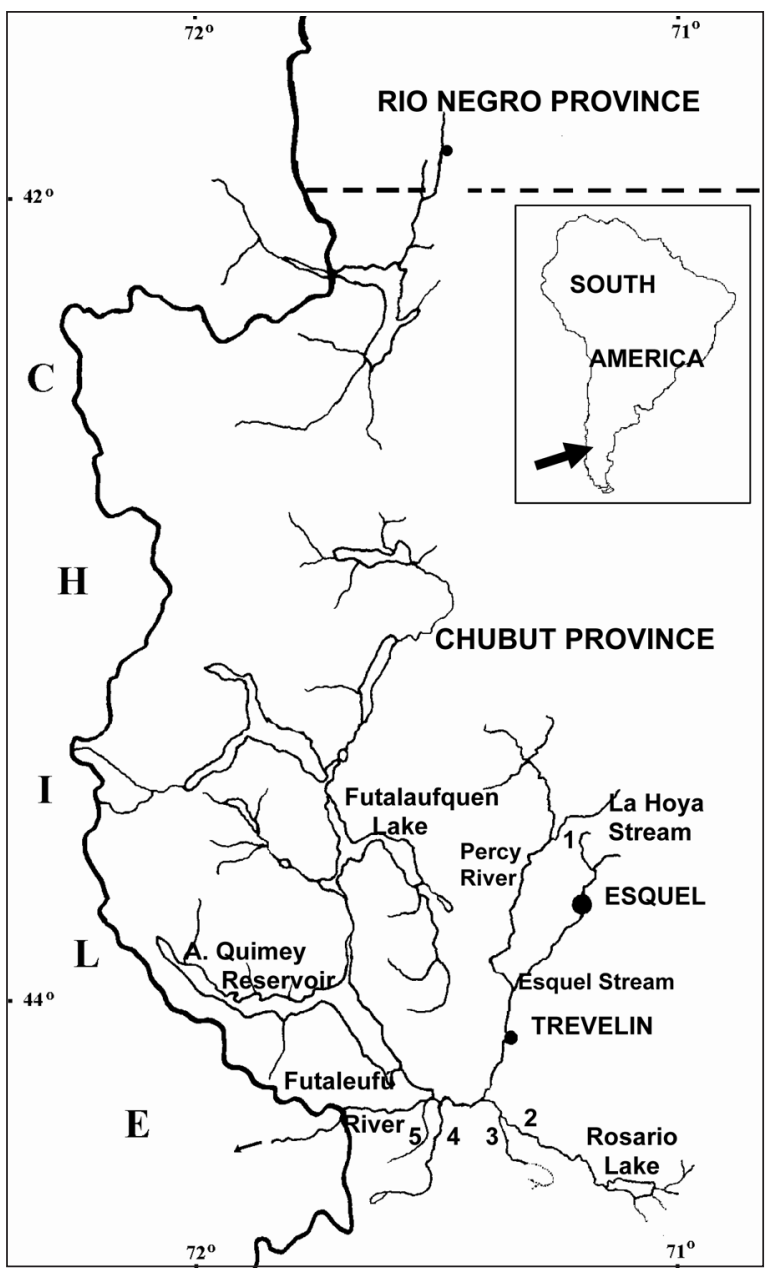

Fig. 1. Map of the Futaleufú basin area, showing its location in South America, and the position of the sampling sites: 1: La Hoya Stream, 2: Nant y Fall Stream 3: Rifleros Stream, 4: Baggilt Stream and 5: Blanco Stream.

rounded by riparian forest composed mainly of deciduous Nothofagus pumilio, the shrubs Fuchsia magellanica, Ribes magellanicum, Mulinum spinosum and the herbaceous Stipa sp. (León et al. 1998). The Blanco, Baggilt, Rifleros, and Nant y Fall streams (lower Futaleufú Basin) are located along the strongly west-east decreasing rainfall gradient characteristic of the eastern side of the Andes, especially between 40 and $43^{\circ} \mathrm{S}$ (Paruelo et al. 1998). They are high gradient streams. Blanco and Baggilt headwaters include small glaciers, and headwater lakes are present in the Baggilt and Nant y Fall catchments. The Blanco and Baggilt catchments are covered by deciduous Nothofagus pumilio forest between 800 and $1300 \mathrm{~m}$, and by the perennial Austrocedrus chilensis (Cupressaceae), which is also common 
in the high forest at the Rifleros stream (over $800 \mathrm{~m}$ ). The downstream portions of the Rifleros and Nant y Fall basins are covered by $N$. antarctica forest. However, at these sites the riparian corridor has been completely invaded by the exotic Salix fragilis.

At each site the percentage of boulder, cobble, gravel, pebble and sand on the stream bed was assessed using a grid $\left(1 \mathrm{~m}^{2}\right)$ (Gordon et al. 1994). Air and water temperature and stream width were measured monthly during a year (1991-1992 in Blanco, Baggilt, Rifleros and Nant y Fall streams, and 2004-2005 in La Hoya stream). Current velocity was measured during the high and low water period at all sites. Discharge was recorded bimonthly but was not available for Blanco and Rifleros. Specific conductance $\left(\right.$ at $\left.20^{\circ} \mathrm{C}\right)$ was measured bimonthly with a Horiba U2-probe.

The data in this paper were assembled from a number of studies previously conducted in the area. Life histories of Antarctoperla michaelseni and Notoperlopsis femina were described from collections made at Baggilt and Rifleros rivers respectively. At these sites, larval samples were taken from September 1991 to July 1992. In addition and to obtain adult specimens, monthly samples from October 2003 to April 2004 and from September 2004 to March 2005 were taken (Blanco, Baggilt, Rifleros and Nant y Fall). Life histories of Aubertoperlailliesi, Senzilloides panguipulli and Klapopteryx kuscheli were assessed from samples taken monthly from July 2004 to June 2005 at La Hoya Stream. In all cases benthic samples were collected from riffles with a Surber sampler $\left(0.09 \mathrm{~m}^{2} ; 250 \mu \mathrm{m}\right.$ mesh). The sampling schedule for adults in La Hoya sites involved monthly visits from October 2004 to April 2005. Because larval collections come from separate research projects the procedures employed to obtain samples were different. Estimates of larval density were obtained from Baggilt and Rifleros streams from each of which eight samples were taken and pooled each month. At La Hoya Stream three samples were taken each month and analyzed, separately. In order to collect more larvae for the description of life histories eight additional Surber samples were taken from La Hoya Stream and pooled on each sampling date. Samples were fixed with $4 \%$ formaldehyde solution, sorted at $5 x$ magnification and stored in $70 \%$ ethyl alcohol. Specimens were identified using available keys (Illies 1963, Mc Lellan 2001, Fernández \& Domínguez 2001).

Shoreline pitfall traps (Stanford 1975, Miserendino \& Stanford 2004) were employed for the collection of teneral adults and emerging nymphs. Pitfall traps were used at all sites (La Hoya, Blanco, Baggilt, Rifleros, Nant y Fall) plus two additional sites in La Hoya Stream. At each site, 5 plastic recipients $\left(1500 \mathrm{~cm}^{3}\right), 12 \mathrm{~cm}$ diameter were embedded in the river bank and concealed by large flat rocks. The cans were half filled with $10 \%$ formalin. A thin film of glycerine was applied to the surface of the fixative, to encumber teneral adults and emerging nymphs that fell into the pitfall traps. The pitfall traps were used continuously and emptied on each sampling trip. Additional adults were collected from each site by sweeping low riparian vegetation. Shrubs, small trees and high grasses on the shoreline were beaten with a sweep net for at least 10 minutes. All organic material, nymphs and adults were preserved in $70 \%$ ethanol. We tried to keep to a monthly schedule for sampling adults at most sites, however, some pitfall traps were vandalized or lost at Rifleros and Nant y Fall (September and November second year). To describe life histories of the species interocular distance was measured at 8-64 times magnification (depending on the size of the species) with a linear eyepiece micrometer inserted in a stereomicroscope (Snellen \& Stewart 1979, Short \& Ward 1980, Richardson 2001). The number of specimens counted and measured for the life history descriptions were: A. illiesi 1,422 larvae and 115 adults, S. panguipulli 163 larvae and 11 adults, $A$. michaelseni 173 larvae and 29 adults, $N$. femina 241 larvae and 9 adults, and K. kuscheli 629 larvae and 116 adults. Sex ratio analysis of the adults was performed per site using Chi-square test $(\mathrm{p}<0.05)$ (Sokal \& Rohlf 1995).

\section{Results}

\section{Environmental features}

As it is a headwater environment La Hoya Stream was narrower and had lower air temperatures than the other sites considered in the study. However, most physicochemical characteristics were similar among sites (Table 1). Some climatic differences (air temperature, rainfall) related to the position of the tributaries in the basin are shown in Fig. 2. Temperature patterns were similar among sites despite the surveys being performed in different years. The discharge regime of running waters in the cordillera is related to rainfall (May-July) and snowmelt (September-October) which was higher in the lower Futaleufú Basin than at La Hoya stream. Most sites were cool and turbulent. The substrate was composed mainly of boulders and cobbles at most sites, however substrates were generally smaller at Rifleros and Nant y Fall (Table 1).

\section{Life histories and emergence patterns}

A. illiesi: Maximum density of nymphs in La Hoya Stream was recorded in July (1088 ind. $\mathrm{m}^{-2}$ ). Very low 


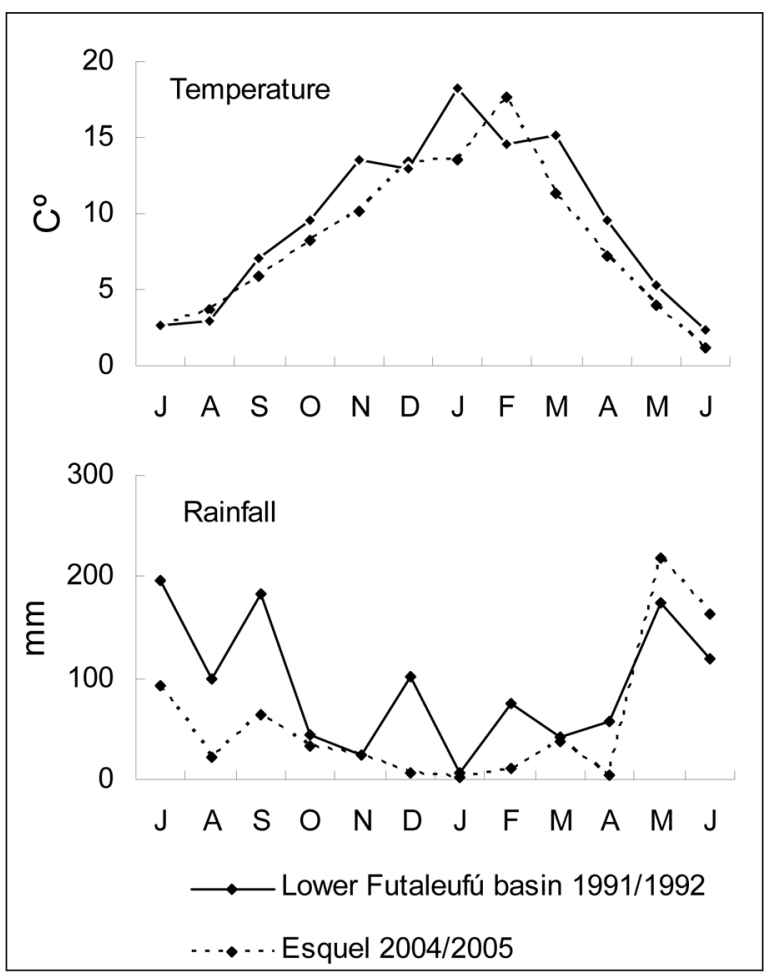

Fig. 2. Climate features (mean air temperature and rainfall) of the upper (Esquel) and lower Futaleufú River basin during the study period. densities of larvae were recorded in January ( 11 ind. $\mathrm{m}^{-2}$ ) (Fig. 3).A. illiesi had a univoltine life history with recruitment of small larvae first seen in February (Fig. 4). Collections of nymphs obtained in March and April were dominated by small individuals. We observed slow growth in autumn followed by a rapid increase in larval size during spring and summer. Final-instar nymphs were collected in October and November. Adults were taken with sweep nets and traps from November to February (Table 2).

S. panguipulli: Nymphs peaked in abundance in La Hoya Stream in July (115 ind. $\mathrm{m}^{-2}$ ), but were not found in October and few nymphs were recorded in September, November, December, February, March and June (Fig. 3). S.panguipulli had a well synchronized, univoltine life history (Fig. 4). Very small nymphs were found in February whereas medium-large nymphs predominated from May to September. Final instar nymphs were taken in monthly samples in December, January and February. The emergence period started in January and extended until mid-April (Table 2).

A. michaelseni: Nymphs peaked in abundance in Baggilt Stream in June (Fig. 3) but none were found in October, November and December. The life history was univoltine (Fig. 4) with adults emerging between October and February and peaking in December at most sites

Table 1. Range, mean and standard deviation (in parenthesis) of the main environmental features of study sites. na: not available. Substratum size: Boul: boulder, Cob: cobble, Peb: pebble.

\begin{tabular}{|c|c|c|c|c|c|c|c|c|c|}
\hline 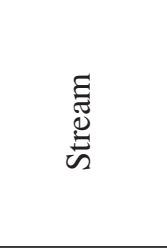 & 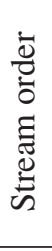 & 总 五 & 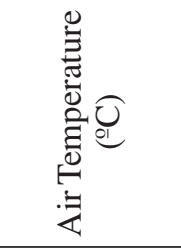 & 离营 & 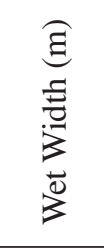 & 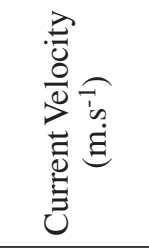 & 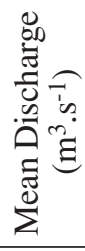 & 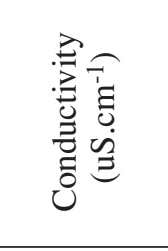 & 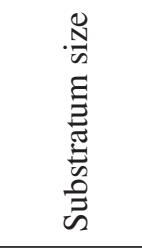 \\
\hline La Hoya & 2 & 1237 & $\begin{array}{c}-3 / 16.5 \\
(7.85 \pm 6.70)\end{array}$ & $\begin{array}{c}1 / 12 \\
(4.75 \pm 3.55)\end{array}$ & $2 / 5$ & $0.55 / 0.83$ & 0.44 & $\begin{array}{c}9 / 92 \\
(28 \pm 26.7)\end{array}$ & Boul/cob \\
\hline Nant y fall & 3 & 310 & $\begin{array}{c}-0.5 / 27 \\
(14.9 \pm 8.8)\end{array}$ & $\begin{array}{c}0 / 16 \\
(10.5 \pm 5.8)\end{array}$ & $8 / 12$ & $0.79 / 0.86$ & 2.47 & $\begin{array}{c}85 / 94 \\
(90.9 \pm 5)\end{array}$ & $\mathrm{Peb} / \mathrm{Sand}$ \\
\hline Rifleros & 3 & 415 & $\begin{array}{c}-0.5 / 24 \\
(14.2 \pm 8.2)\end{array}$ & $\begin{array}{c}0 / 18 \\
(11.6 \pm 5.8)\end{array}$ & $9.3 / 12$ & $0.38 / 0.86$ & na & $\begin{array}{c}37 / 84 \\
(62.8 \pm 32)\end{array}$ & Cob/peb \\
\hline Baggilt & 3 & 460 & $\begin{array}{c}-0.5 / 25 \\
(14.4 \pm 8.1)\end{array}$ & $\begin{array}{c}0 / 14 \\
(9.1 \pm 4.4)\end{array}$ & $18 / 20$ & $0.46 / 0.85$ & 4.09 & $\begin{array}{c}17 / 34 \\
(21.6 \pm 18)\end{array}$ & Boul/cob \\
\hline Blanco & 2 & 450 & $\begin{array}{c}-0.5 / 23 \\
(13.18 \pm 7.9)\end{array}$ & $\begin{array}{c}0 / 12 \\
(8.4 \pm 3.9)\end{array}$ & $15 / 35$ & $0.25 / 0.56$ & na & $\begin{array}{c}11 / 32 \\
(16.8 \pm 52)\end{array}$ & Boul/cob \\
\hline
\end{tabular}




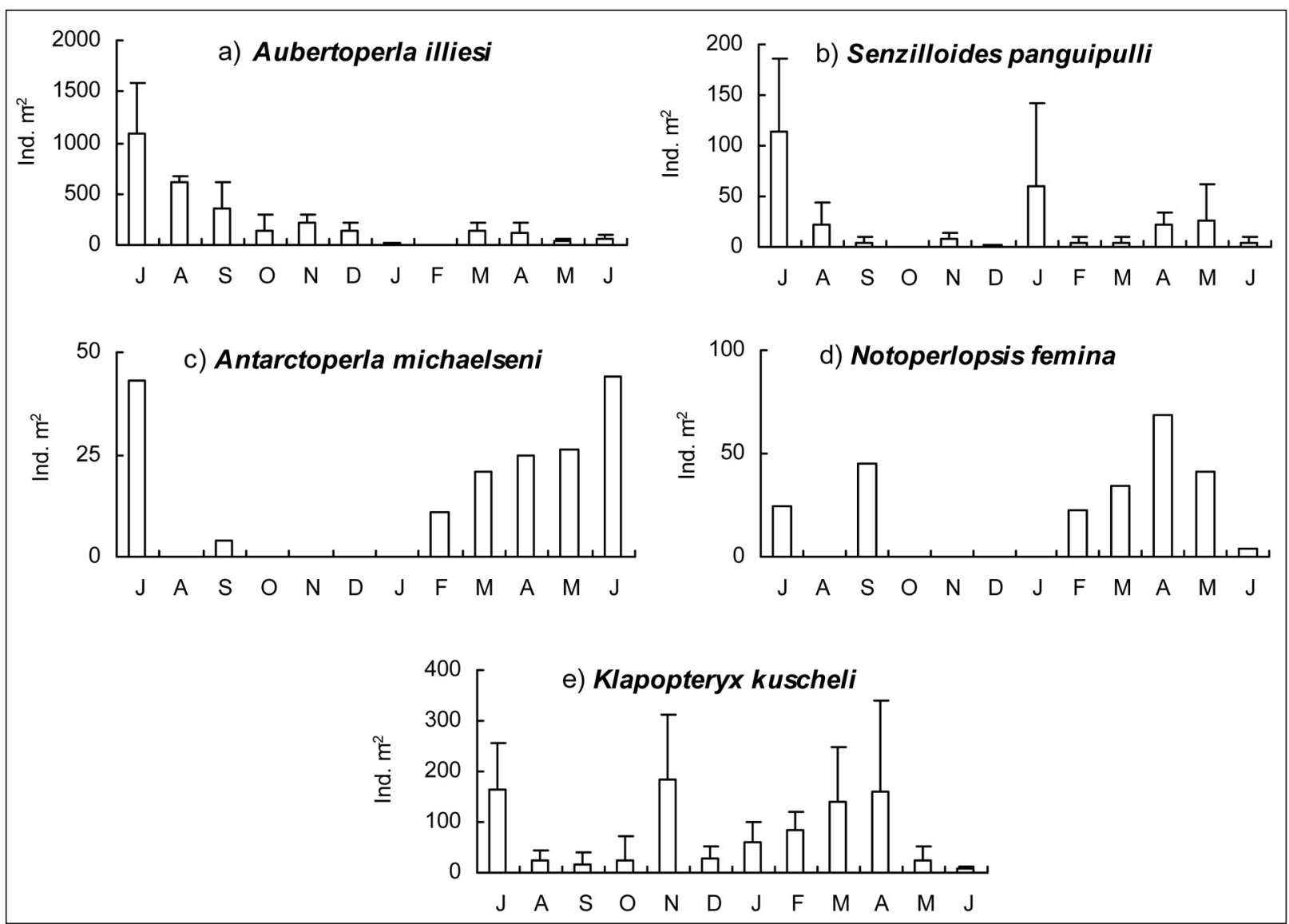

Fig. 3. Seasonal density patterns of stonefly species in benthic samples. a) A. illiesi b) S. panguipulli, and e) K. kuscheli (La Hoya stream), mean values $( \pm \mathrm{SD}$ ) and $n=3$. c) A. michaelseni and d) N. femina (Baggilt and Rifleros stream), monthly cumulative values of eight pooled Surber samples.

(Table 2). Early instar larvae began to appear during February and grew fast in the following two months. We found that sex ratio was male-biased in A. michaelseni at Baggilt, and this pattern was statistically significant (Table 2, $\mathrm{X}^{2}=13.8, \mathrm{p}<0.05$ ).

N.femina: $N$. femina had a univoltine life history with emergence starting in September before the other species (Table 2). Larvae appeared in February and were most abundant in April (Fig. 3). Mature nymphs were collected from July and September (Fig. 4). All the adult males captured were brachypterous.

K. kuscheli: Maximum density of nymphs was recorded in La Hoya Stream in November (185 ind. $\left.\mathrm{m}^{-2}\right)$ and minimum abundance was in June ( 7 ind. $\mathrm{m}^{-2}$ ) (Fig. 3 ). We observed small nymphs from November to March (Fig. 5), which suggests that hatching occurred throughout spring and summer. Most mature nymphs were found from January to April. K. kuscheli appeared to have a 2-year life history based on this species large size and the cooler water temperatures of La Hoya stream. Numerous adults were collected in pitfall traps during late-spring and summer (November-January) (Table 2) and as in N.femina all males were brachypterous. However, in $K$. kuscheli at least $50 \%$ of the females were also short winged. We observed that sex ratios were male-biased in $K$. kuscheli at both sites, differences were statistically significant at Baggilt due to small sample size at La Hoya (Table 2, $\mathrm{X}^{2}=56.5, \mathrm{p}<0.05$ ).

We were unable to describe the life histories of several other species including Limnoperla jaffuelli because few nymphs were found in benthic samples. However, we captured 24 adults of L. jaffuelli in Nant y Fall, Blanco and Rifleros Streams between December and February (Table 2). Except for S. panguipulli we did not capture adults of stoneflies from April onwards at any of the sampled sites. 


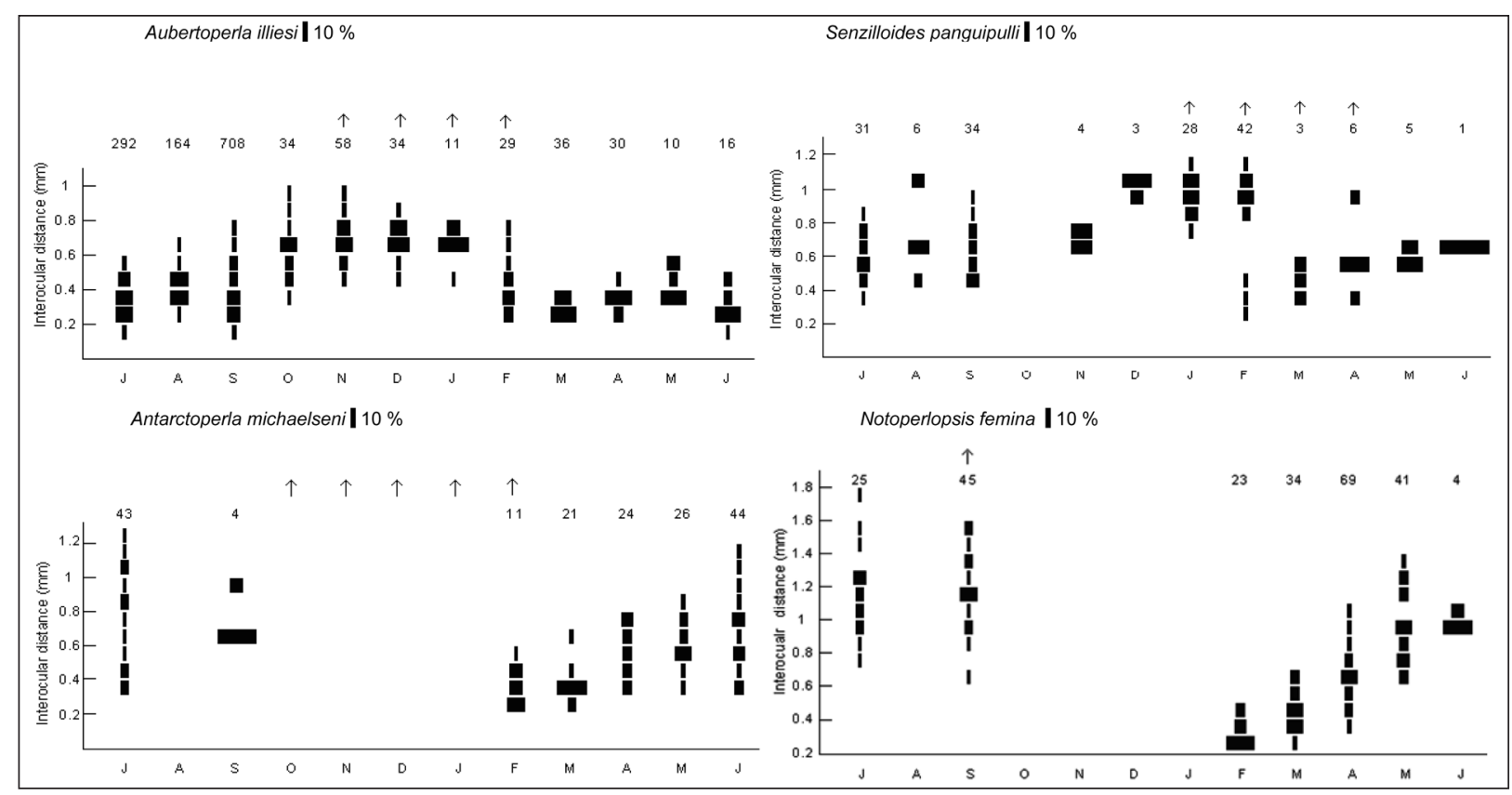

Fig. 4. Seasonal development patterns of Aubertoperla illiesi, Senzillloides panguipulli (La Hoya stream), and Antarctoperla michaelseni and Notoperlopsis femina (Baggilt and Rifleros stream respectively) in the Futaleufu Basin, Patagonia Argentina. Arrow indicate adult emergence period. Numerals above histograms show numbers of larvae measured each month.

\section{Discussion}

This is the first study of stonefly life histories in Patagonian streams. Our results indicate that the small-medium sized $(0.5-1.5 \mathrm{~cm})$ Aubertoperla illiesi, Senzilloides panguipulli,Antarctoperla michaelseni and Notoperlopsis femina (Gripopterygidae) had univoltine life histories in the Futaleufú Basin. Similarly, many small-medium sized Plecoptera species in the Northern Hemisphere have univoltine life histories (Harper et al. 1991, Tierno de Figueroa et al. 2001, Richardson 2001) as do numerous Southern Hemisphere Gripopterygidae including Antarctoperlinae (Winterbourn 1966, 1978, Hynes \& Hynes 1975, Bunn 1988, Death 1990).

In the present study N.femina had a fast winter growth cycle with well synchronized larval development and a short period of adult emergence. Notoperlopsis femina adults were collected in September, consistent with the report of McLellan et al. (2006) for this species in the Gualjaina River (Precordillera and steppe transition at 500 m.a.s.l., $42^{\circ} 32^{\prime} 06^{\prime}$ 'S, $70^{\circ} 25^{\prime} 44^{\prime \prime} \mathrm{W}$ ). As in our work all males they collected were short-winged. The life history of A. michaelseni was less well synchronized because of an extended hatching period during autumn, and an extended period of adult emergence (November to February in Baggilt Stream). Senzilloides panguipulli also had an extended hatching period during winter but adult emergence started in January and continued until April. In contrast, Aubertoperla illiesi had slow winter development in La Hoya Stream, rapid nymphal growth in spring, and emergence from October to February.

In the Futaleufú Basin, emergence of A. illiesi appeared to begin later at La Hoya Stream (1237 m a.s.1.) than at Nant y Fall Stream ( $415 \mathrm{~m}$ a.s.1.) and may reflect differences in temperature patterns, which in turn depend on elevation. Nevertheless, our results suggest that most of the gripopterygid species studied had well synchronized emergence patterns. This situation is consistent with the findings of Hynes \& Hynes (1975) and Bunn (1988) who concluded that synchronized seasonal life histories appeared to be the rule rather than the exception for gripopterygid stoneflies in temperate southern Australia. In contrast, the relatively few New Zealand stoneflies studied have a mixture of well- and poorly synchronized life histories (Scarsbrook 2000).

Synchronized emergence is a widespread phenomenon among insects because it facilitates the finding of mates and reduces the exposure of adult individuals to predation (Stewart \& Stark 1993, Dieterich \& Anderson 1995). Richardson (2001) mentioned that there can be a degree of phylogenetic constraint in the timing of life histories, while environmental factors such as temperature 
Table 2. Numbers of adult female and male Plecoptera collected at five sites in the Futaleufú River basin in two consecutive years (La Hoya sites; 2004-2005; Blanco, Baggilt, Rifleros and Nant y Fall: 2003-2004). TF: total females, TM: total males. - no data * Significant differences $\left(\mathrm{p}<0.05\right.$, critical value $\left.\mathrm{X}_{(0.05,1)}=3.84\right)$.

\begin{tabular}{|c|c|c|c|c|c|c|c|c|c|}
\hline \multicolumn{3}{|c|}{ 2003-04 } & & & & \multicolumn{4}{|c|}{ 2004-05 } \\
\hline Oct & Nov & Dec & Jan & Feb & Mar & Apr & Sep/Oct & Nov & TF TM \\
\hline
\end{tabular}

La Hoya Aubertoperla $00 \begin{array}{llllllllllllllllllll} & 0 & 20 & 30 & 21 & 17 & 4 & 5 & 2 & 2 & 0 & 0 & 0 & 0 & - & - & - & - & 47 & 54\end{array}$ illiesi

$\begin{array}{lllllllllllllllllllllll}\text { Klapopteryx } & 0 & 0 & 1 & 1 & 0 & 6 & 2 & 1 & 0 & 0 & 0 & 0 & 0 & 0 & - & - & - & - & 4 & 8\end{array}$ kuscheli

$\begin{array}{lllllllllllllllllllllll}\text { Senzilloides } & 0 & 0 & 0 & 0 & 0 & 0 & 0 & 1 & 4 & 4 & 0 & 1 & 1 & 0 & - & - & - & - & 5 & 6\end{array}$ panguipulli

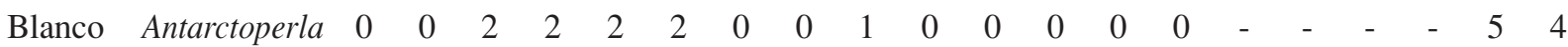
michaelseni

$\begin{array}{llllllllllllllllllllll}\text { Aubertoperla } & 0 & 0 & 4 & 4 & 0 & 2 & 0 & 0 & 0 & 0 & 0 & 0 & 0 & 0 & - & - & - & - & 4 & 6\end{array}$ illiesi

$\begin{array}{llllllllllllllllllllll}\text { Baggilt Antarctoperla } & 1 & 0 & 4 & 2 & 0 & 9 & 3 & 9 & 0 & 1 & 0 & 0 & - & - & 0 & 9 & 5 & 10 & 13 & 40 *\end{array}$ michaelseni

$\begin{array}{lllllllllllllllllllll}\text { Aubertoperla } & 0 & 0 & 2 & 2 & 5 & 4 & 3 & 5 & 2 & 3 & 0 & 0 & - & - & 1 & 10 & 8 & 8 & 21 & 32\end{array}$ illiesi

$\begin{array}{lllllllllllllllllllll}\text { Klapopteryx } & 0 & 0 & 0 & 0 & 5 & 13 & 4 & 7 & 0 & 9 & 0 & 0 & - & - & 0 & 0 & 5 & 62 & 14 & 91 *\end{array}$ kuscheli

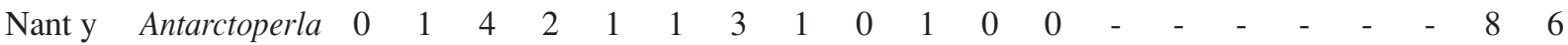

Fall michaelseni

$\begin{array}{llllllllllllllllllllll}\text { Aubertoperla } & 2 & 2 & 14 & 6 & 9 & 9 & 5 & 4 & 0 & 0 & 0 & 0 & - & - & - & - & - & - & 30 & 21\end{array}$ illiesi

$\begin{array}{llllllllllllllllllllll}\text { Limnoperla } & 0 & 0 & 9 & 30 & 9 & 5 & 9 & 6 & 0 & 0 & 0 & 0 & - & - & - & - & - & - & 27 & 41\end{array}$ jaffueli

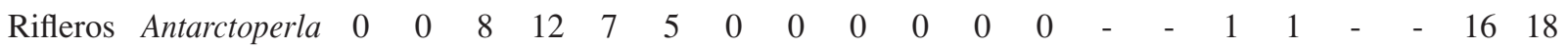
michaelseni

$\begin{array}{llllllllllllllllllllll}\text { Limnoperla } & 0 & 0 & 10 & 7 & 3 & 2 & 1 & 1 & 0 & 0 & 0 & 0 & - & - & 0 & 0 & - & - & 14 & 10\end{array}$ jaffueli

$\begin{array}{llllllllllllllllllllll}\text { Notoperlopsis } & 0 & 0 & 0 & 0 & 0 & 0 & 0 & 0 & 0 & 0 & 0 & 0 & - & - & 6 & 3 & - & - & 6 & 3\end{array}$ femina

and day length can also constrain growth and emergence patterns (Sweeney 1984; Ward 1985, 1992). We suspect that some of the observed differences in emergence periods of our gripopterygid species such as A. illiesi were related to differences in water temperature at the various sites. Thus, February was the warmest month at La Hoya Stream during the study period, whereas January was the warmest month in the lower Futaleufú River basin. How- 


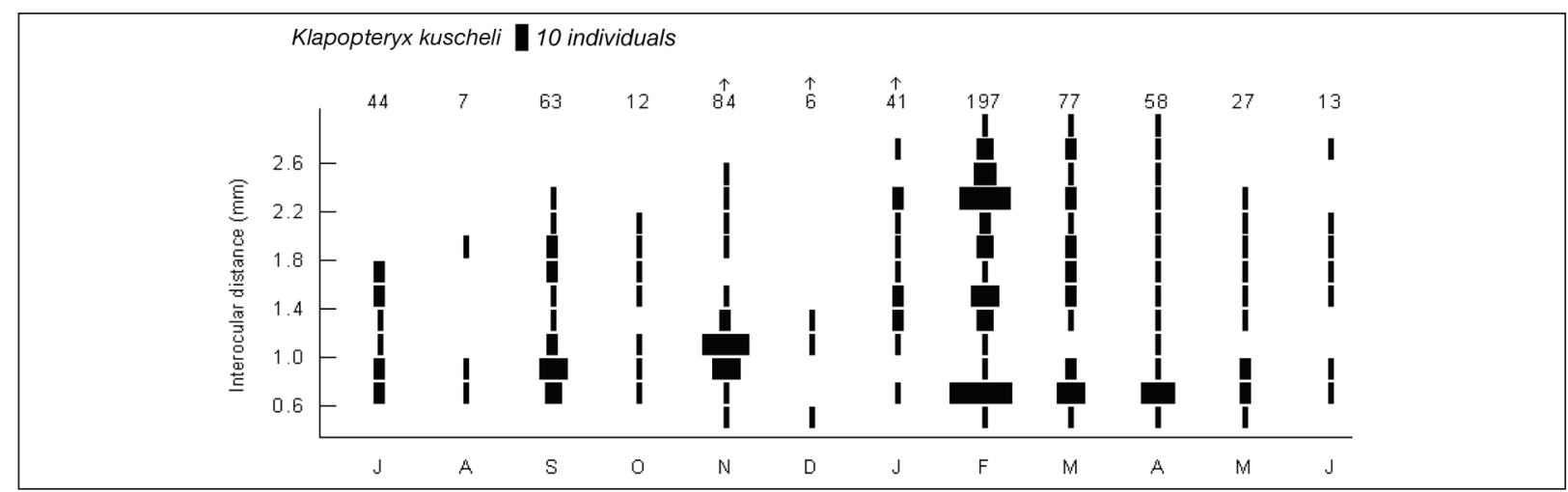

Fig. 5. Seasonal development pattern of Klapopteryx kuscheli in La Hoya stream, July 2004-June 2005. Arrow indicate adult emergence period. Numerals above histograms show numbers of larvae measured each month.

ever, this should be taken with care since only 4 adults of A. illiesi were collected at Nant y Fall during October.

Long life histories are typical of many larger predatory and detritivorous stoneflies (Merrit \& Cummins 1996) such as the New Zealand eustheniid Stenoperla prasina and the austroperlid Austroperla cyrene (Scarsbrook 2000). Consistent with this pattern we found that the large austroperlid Klapopteryx kuscheli (mature larval length $>3 \mathrm{~cm}$ ) that feeds mostly on Nothofagus pumilio leaves (Albariño \& Balseiro 1998) took about two years to complete its life cycle. Semivoltine (2 year) life histories have also been reported for predator and detritivore stoneflies in north-temperate regions (e.g., predators: the chloroperlids Sweltsa onkos and S. fidelis, detritivores: the leuctrid Depaxia augusta) (Harper et al. 1991, Dieterich \& Anderson 1995, Richardson 2001).

Extended larval recruitment, differential growth rates of males and females and cohort splitting (i.e., a separation into faster and slower-growing larval groups) are all found in some aquatic insects with long life cycles and extended emergence periods (Butler 1984, Townsend \& Pritchard, 1998). Although K. kuscheli is one of the largest stoneflies inhabiting Patagonian running waters we found no evidence of cohort splitting and adults were seen only in late spring and summer. However, early instar larvae were present from November to May indicating extended recruitment. A study on the life cycle of the even larger Pteronarcys californica (Pteronarcyidae) in Alberta showed that it spent at least 4 years in the larval stage, had extended larval recruitment as in K. kuscheli, probable cohort splitting, and a high degree of synchrony in adult emergence.

Since emergence is a single event in a life history, the sex of emergents must influence the mating behavior and reproductive success (Stewart 1994). Differences in sex ratio have been observed for several species of stoneflies (Zwick 1990, Sheldon 1999, Petersen et al., 2006). Our study suggests that sex ratios of $K$. kuscheli and $A$. michaelseni were male-biased in Baggilt stream. Similar observation has been reported for the stonefly Calineuria in a cold stream in Montana (Sheldon, 1999). However, sex-specific differences can be related with adult behavior, longevity and habitat usage (Petersen et al., 2006). Then, it is possible that pit-fall traps effectively caught more males (all brachypterous) than females of $K$. kuscheli. Brachyptery is more common in permanent aquatic habitats (Harrison 1980) and frequently associated with an increase in altitude and latitude, particulary where insects are exposed to cool temperatures and high winds (McLellan 2001).

The life histories of many southern hemisphere stream invertebrates appear to be seasonally flexible in contrast to the more synchronous life cycles exhibited by numerous north-temperate species, and may be a consequence of selection driven by climatic unpredictability and equability (Winterbourn 1995, Lake 1995, Gonser \& Spies 1997, Scarsbrook 2000). Flexible life cycles are found in the mayfly species Meridialaris chiloeensis and Metamonius anceps that inhabit La Hoya Stream (Hollmann \& Miserendino 2006) but not in the Plecoptera species considered in this paper. Thus, in La Hoya, Baggilt and Rifleros streams, stonefly life histories were well synchronized and emergence periods were restricted to a few months. We recognize that latitude and altitude can have strong effects on emergence patterns resulting in synchrony (Füreder et al. 2005), and can account for at least some of the geographic variation in the timing of emergence (Richardson 2001). For this reason extrapolation of our findings to streams elsewhere in Patagonia need to be made with caution. 


\section{Acknowledgements:}

Special thanks to G. Alday, C. Di Prinzio, P. Diaz, A. Humai, A. Gómez and R. Magallanes for valuable help during the sampling and to C. Brand for laboratory assistance. We are grateful to Dr. Miguel Archangelsky for helpful comments on the English version of the paper. We greatly appreciate the reviews of Dr. Mike Winterbourn for his thoughtful and constructive suggestions. Thanks to anonymous reviewers for valuable comments that greatly improved the manuscript. This is Scientific Contribution $n^{\circ} 23$ from LIESA.

\section{References}

Albariño R. 1997. - Spatial distribution of Plecoptera from an Andean-Patagonic lotic environment in Argentina. Rev. Brasil. Biol., 57, 629-636.

Albariño R. \& Balseiro E. 1998. - Larval size and leaf conditioning in the breakdown of Nothofagus pumilio leaves by Klapopteryx kuscheli (Insecta, Plecoptera) in a South Andean stream. Int. Rev. Hydrobiol., 83, 397-404.

Boothroyd I. 2000. - Biogeography and diversity. Pages 30-52 In: New Zealand stream invertebrates: ecology and implications for management. Collier K. J. and Winterbourn M. J. (eds) New Zealand Limnological Society, Christchurch. New Zealand.

Brittain J. 1991. - Life history characteristics as a determinant of the response of mayflies and stoneflies to man-made environmental disturbance (Ephemeroptera and Plecoptera). Pages 539-546 In: Overview and strategies of Ephemeroptera and Plecoptera. Alba-Tercedor J. \& Sanchez Ortega A. (eds). Sandhill Crane Press. Gainesville, Fla. USA.

Bunn S.E. 1988. Life histories of some benthic invertebrates from streams of the northern Jarrah forest, Western Australia. Aust. J. Mar. Freshwat. Res., 39,785-804.

Butler M.G. 1984. - Life histories of aquatic insects. Pages 24-55 In: The ecology of aquatic insects. Resh V.H. \& Rosenberg D.M. (eds). Praeger. New York

Cayrou J. \& Céréghino R. 2005. - Life-cycle phenology of some aquatic insects: implications for pond conservation. Aquat. Conserv., 5, 559-571.

Death R.G. 1990. - A new species of Zelandobius (Plecoptera: Gripopterygidae: Antarctoperlinae) from New Zealand. N. Z. Nat. Sci., 17, 23-28.

Dieterich M. \& Anderson N.H. 1995. - Life cycles and food habits of mayflies and stoneflies from temporary streams in western Oregon. Freshwat. Biol., 34, 47-60.

Fernández H.R. \& Domínguez E. 2001. - Guía para la determinación de artrópodos bentónicos sudamericanos. Editorial Universitaria de Tucumán. Argentina. 282 pp.

Füreder L., Wallinger M. \& Burger R. 2005. - Longitudinal and seasonal pattern of insect emergence in alpine streams. Aquat. Ecol., 39, 67-78.

Gonser T. \& Spies M. 1997. - Southern Hemisphere Symbiocladius (Diptera, Chironomidae) and their mayfly hosts (Ephemeroptera, Leptophlebiidae) Pages: 455-466 In: Ephemeroptera \& Plecoptera: Biology-Ecology-Systematic. Landolt P. \& Sartori M. (eds). MTL, Fribourg.

Gordon N.D., Mc Mahon T.A. \& Finlayson B.L. 1994. - Stream hydrology, an introduction for ecologists. Wiley, New York. 526 pp.

Harper P.P., Lauzon M. \& Harper F. 1991. - Life cycles of sundry stoneflies (Plecoptera) from Quebec. Rev D'entomologie du Quebec., 36, 28-42

Harrison R.G. 1980. - Dispersal polymorphisms in insects. Ann. Rev. Ecol. Syst. 11: 95-118.
Hitchings T.R. \& Staniczek A.H. 2003. - Nesameletidae (Insecta: Ephemeroptera). Fauna of New Zealand 46. Manaaki Whenua Press, Lincoln. 72 pp.

Hollmann M.E.T \& Miserendino M.L. 2004. - Hábitat y composición de la dieta de larvas de Metamonius anceps (Ephemeroptera) y Senzilloides panguipulli (Plecoptera) en arroyos de montaña en Patagonia. II Reunión Binacional de Ecología. Mendoza. Pág. 171.

Hollmann M.E.T.\& Miserendino M.L. 2006. - Habitat type and life history of the mayflies Metamonius anceps Eaton (Nesameletidae) and Meridialaris chiloeensis Demoulin (Leptophlebiidae) in a Patagonian mountain stream. Ann. Limnol. - Int. J. Lim., 42, 233-240.

Hynes H.B.N. \& Hynes M.E. 1975. - The life histories of many of the stoneflies (Plecoptera) of south-eastern mainland Australia. Aust. Mar. Freshwat. Res., 27, 61-70.

Illies J. 1963. - Revision der sudamerikanischen Gripopterygidae (Plecoptera). Mitt. Schweiz. Ent. Ges., 3,147-247

Illies J . 1965. - Phylogeny and zoogeography of the Plecoptera. Ann. Rev. Entomol., 10, 117-140.

Lake P.S. 1995. - Of floods and droughts, River and Stream Ecosystems of Australia. Pages: 650-693 in Ecosystems of the world. River and stream ecosystems Cushing C.E., Cummins K.W. \& Minshall G.W. (eds.). Elsevier, New York.

León R., Bran D., Collantes M., Paruelo J.M. \& Soriano A. 1998. Grandes unidades de vegetación de la Patagonia extra andina. Ecología Austral, 8, 125-144.

McLellan I. 2001. - A revision of South American Austroperlidae (Plecoptera), Aquat. Insect., 23: 233-251

McLellan I., Miserendino M.L. \& Hollmann M.E.T. 2006. - Two new species of Notoperla (Plecoptera: Gripopterygidae) and a redescription of Notoperlopsis femina. Zootaxa, 1140, 53-68.

Merrit, R. W. \& Cummins K. W. 1996. - An introduction to the aquatic insects of North America. Kendal Hunt Publishing Co. $862 \mathrm{pp}$.

Miserendino, M.L. 2000. - Distribución y variación estacional de Plecoptera en un sistema fluvial de cordillera Patagónica. Rev. Soc. Entomol. Arg., 59, 149-160

Miserendino M.L. 2001. - Macroinvertebrate assemblages in Andean Patagonian rivers and streams. Hydrobiologia, 444, 147-158.

Miserendino M.L. 2006. - Seasonal and spatial distribution of stoneflies in the Chubut River (Patagonia, Argentina). Hydrobiologia, 568, 263-274.

Miserendino M.L. \& Pizzolón L.A. 2000. - Macroinvertebrates of a fluvial system in Patagonia: altitudinal zonation and functional structure. Arch. Hydrobiol.,150, 55-83.

Miserendino M.L. \& Pizzolón L.A. 2003. - Distribution of macroinvertebrate assemblages in the Azul-Quemquemtreu river basin, Patagonia, Argentina. New. Zeal. J. Mar. Fresh., 23 (3), 525-539.

Miserendino M.L. \& Pizzolon L.A. 2004. - Interactive effects of basin features and land use change on macroinvertebrate communities of headwater streams in the Patagonian Andes. Riv. Res. \& Appl., 20(8), 967-982.

Miserendino M.L. \& Stanford J.A. 2004. - Life histories, abundance and distribution of stoneflies in the Flathead River Basin Montana (USA): continuity over 30 years. In Abstract of the XI International Conference on Ephemeroptera and XV International Symposium on Plecoptera, August 22 - 29. Flathead Lake Biological Station The University of Montana. Polson, Montana (USA). $70 \mathrm{pp}$. 
Paruelo J.M., Beltrán A., Jobbagy E., Sala O. \& Golluscio R.A. 1998. - The climate of Patagonia: general patterns and controls on biotic processes. Ecología Austral., 8, 85-101.

Petersen I., Masters Z., Ormerod S.J., \& Hildrew A. G. 2006. - Sex ratio and maturity indicate the local dispersal and mortality of adult stoneflies. Freshwat. Biol., 51, 1543-1551.

Perry S.A., Perry W.B. \& Stanford J.A. 1986. - Effect of thermal regime on size, growth rates and emergence of two species of stoneflies (Plecoptera: Taeniopterygidae, Pteronarcyidae) in the Flathead River, Montana. Am. Midl. Nat., 117, 83-93.

Quinn J.M.\& Hickey C.W. 1990. - Characterization and classification of benthic invertebrate communities in $88 \mathrm{New}$ Zealand rivers in relation to environmental factors. N. Z. J. Mar. Freshwat. Res., 24, 387-409.

Richardson J.S. 1991. - Seasonal food limitation of detritivores in a montane stream: an experimental test. Ecology, 72: 873-887.

Richardson J.S. 2001. - Life cycle phenology of common detritivores from a temperate rainforest stream. Hydrobiologia, 455, 87-95.

Scarsbrook M.R. 2000. - Life histories. Pages 76-99 In: New Zealand stream invertebrates: ecology and implications for management. Collier K.J. \& Winterbourn M.J. (eds) New Zealand Limnological Society, Christchurch.

Sheldon A.L. 1999. - Emergence patterns of large stoneflies (Plecoptera: Pteronarcys, Calineura, Hesperoperla) in a Montana River. Great Basin Nat., 59, 169-174.

Short R.A. \& Ward J.V. 1980. - Life cycle and production of Skwala parallela (Frison) (Plecoptera: Perlodidae) in a Colorado montane stream. Hydrobiologia, 69,173-175.

Snellen R.K. \& Stewart K.W. 1979. The life cycle of Perlesta placida (Plecoptera: Perlidae) in an intermittent stream in northern Texas. Ann. Entomol. Soc. Am., 72, 659-666.

Sokal, R. R. \& Rohlf, F. J. 1995. - Biometry. 3rd edition.W.H. Freeman and Company: New York.

Stanford J.A. 1975. - Ecological studies of Plecoptera in the upper Flathead and Tobacco Rivers, Montana. Phd Thesis, University of Utah, Utah, USA.. 238 pp.

Statzner B. \& Resh V.H. 1993. - Multiple-site and year analyses of stream insect emergence: a test of ecological theory. Oecologia., 96, 65-79.
Stewart K.W. 1994. - Theoretical considerations of mate finding and other adult behaviors of Plecoptera. Aquat. Insects., 16, 95-104.

Stewart K.W. \& Stark B.P. 1993. - Nymphs of North American stonefly genera (Plecoptera). University of Texas, Denton Texas.460 pp.

Sweeney B.W. 1984. - Factors influencing life-history patterns of aquatic insects. Pages: 56-100 In: The ecology of aquatic insects. Resh V.H. \& Rosenberg D.M. (eds) Praeger. New York.

Townsend G.D. \& Pritchard G. 1998. - Larval growth and development of the stonefly Pteronarcys californica (Insecta: Plecoptera) in the Crowsnest River, Alberta Can. J. Zool., 76,12: 2274-2280.

Tierno de Figueroa J.M., Luzón-Ortega J.M.\& Sanchez-Ortega A. 2001. - Fenología de los plecópteros (Insecta, Plecoptera) de Sierra Nevada (Granada, Spain). Zool. Baetica., 12, 49-70.

Vannote R.L., Minshall G.W., Cummins K.W., Sedell J.R. \& Cushing C.E. 1980. - The river continuum concept. Can. J. Fish. Aquat. Sci., 37,130-137.

Wais I.R., Vila A.R. \& De Cabo L.I. 1987. - Las ninfas de plecópteros de los parques nacionales Nahuel Huapi y Lanin, Argentina. Rev. Mus. Arg. de Cienc. Nat., 6, 15-21.

Ward J.V. 1985. - Thermal characteristics of running waters. Hydrobiologia., 125, 31-46.

Ward J.V. 1992. - Aquatic insect ecology. Wiley, New York. 438 pp.

Winterbourn M.J. 1966. - Studies on New Zealand stoneflies. 2. The ecology and life history of Zelandoperia maculata. (Hare) and Aucklandobius trivacuatus (Tillyard)- Gripopterygidae. $N Z \mathrm{Jl}$ Sci., 9, 312-323.

Winterbourn M.J. 1978. - The macroinvertebrate fauna of a New Zealand forest stream. N. Z. J. Zool., 5,157-169.

Winterbourn M.J. 1995. - Rivers and streams of New Zealand. Pages 695-716 in Ecosystems of the world. River and stream ecosystems Cushing C.E., Cummins K.W. \& Minshall G.W. (eds.). Elsevier, New York.

Winterbourn M.J., Rounick J.S. \& Cowie B. 1981. - Are New Zealand stream ecosystems really different? N Z J Mar Freshwat Res., 15, 321-328.

Zwick P. 1990. - Emergence, maturation and upstream oviposition flights of Plecoptera from the Breitenbach, with notes on the adult phase as a possible control of stream insect populations. Hydrobiologia, 194: 207-223. 